\title{
Mineral trioxide aggregate as root canal filing material: comparative study of physical properties
}

\author{
MTA como cimento endodôntico: estudo comparativo de \\ propriedades físicas
}

\begin{abstract}
Purpose: This study evaluated some physical properties of two commercial MTA cements regarding it use as root canal filling material.

Methods: The compression strength (CS) of the evaluated materials was performed after 21 hours or 14 days of water immersion. The materials' radiopacity (RD) was measured according to aluminum thickness. Regarding setting time (ST), both initial and final times were measured. The solubility (SB) was calculated according to percentage of lost mass after water storage. The $\mathrm{pH}$ measurement was performed in three different times (initial, 1 and 24 hours) of water storage. All tests were performed according to ISO 6876-2:2001.

Results: Both cements showed that $\mathrm{CS}$ and $\mathrm{pH}$ were as in accordance with ISO standard. The two cements exhibited RD values higher than the equivalent limit of $3 \mathrm{~mm}$-aluminum. Both materials exhibited SB values within the recommended limit of $3 \%$. ST and $\mathrm{pH}$ also are in accordance with ISO 6876-2:2001. Additional SEM surface evaluation showed both amorphous and crystalline phase for both cements.

Conclusion: It is possible to conclude that all evaluated materials are in accordance with ISO standard, allowing its use as root canal filling material.
\end{abstract}

Key words: Dental pulp cavity; root canal filling materials; Endodontics

\section{Resumo}

Objetivo: Este estudo avaliou as propriedades físicas de dois cimentos MTA disponíveis comercialmente.

Metodologia: A resistência a compressão (CS) dos materiais avaliados foi realizada após 21 horas e 14 dias de imersão em água. A avaliação da radiopacidade (RD) dos materiais foi mensurada em função de espessura de alumínio. Com relação à propriedade de tempo de presa (ST), tanto os tempos de presa inicial e final foram mensurados. A solubilidade foi calculada em função da percentagem de massa perdida após armazenamento em água. Os valores de $\mathrm{pH}$ foram mensurados em três diferentes tempos (inicial, 1 e 24 horas) de armazenamento em água. Todos os testes foram realizados de acordo com a norma ISO 6876-2:2001.

Resultados: Ambos os materiais apresentaram valores de $\mathrm{CS}$ e $\mathrm{pH}$ em acordo com os valores da norma ISO. Os dois cimentos apresentaram RD superiores ao limite de $3 \mathrm{~mm}$ de alumínio. Ambos os materiais mostraram resultados de SB inferiores ao limite de $3 \%$. ST e pH também estão de acordo com a norma ISO 6876-2:2001. Adicionalmente foram avaliadas as superfícies dos materiais por MEV, e ambos apresentaram fases estruturais amorfas e cristalinas.

Conclusão: Concluiu-se que ambos os materiais avaliados estão de acordo com as normas ISO, permitindo o seu uso como material de preenchimento de canais radiculares.

Palavras-chaves: Cavidade pulpar dental; Materiais de preenchimento radicular; Endodontia

\author{
Wander José da Silva ${ }^{a}$ \\ Paulo Henrique Couto Souzab \\ Edvaldo Antonio Ribeiro Rosa ${ }^{\text {b }}$ \\ Altair Antoninha Del Bel Cury ${ }^{a}$ \\ Rodrigo Nunes Rached ${ }^{b}$
}

\begin{abstract}
a Department of Prosthodontics and Periodontology, Faculty of Dentistry of Piracicaba, State University of Campinas, Piracicaba, SP, Brazil

b Department of Dentistry, Pontificial University Catholic of Paraná, Curitiba, PR, Brazil
\end{abstract}

\author{
Correspondence: \\ Wander José da Silva \\ Piracicaba Dental School, P.O. Box 52 \\ University of Campinas - UNICAMP \\ Piracicaba, SP - Brazil \\ 13414-903 \\ E-mail: wanderjose@biofilmresearcher.com
}

Received: July 1, 2010

Accepted: October 4, 2010

Conflict of Interest Statement: The authors state that there are no financial and personal conflicts of interest that could have inappropriately influenced their work.

Copyright: (C) 2010 Silva et al.; licensee EDIPUCRS. This is an Open Access article distributed under the terms of the Creative Commons AttributionNoncommercial-No Derivative Works 3.0 Unported License. 


\section{Introduction}

Mineral trioxide aggregate (MTA) cement was first cited in 1993 (1) and has been the first choice of material for a variety of surgical and non-surgical applications in endodontics, including root-end filling, repair of root or furcal perforations, open apices and direct pulp capping (2-6). The biocompatibility of MTA material has been shown to be acceptable for subcutaneous implants $(7)$, pulp capping $(3,4)$ and cell cultures (8). Recent studies showed a good biocompatibility of MTA and osteoformation $(9,10)$, that turns it possible to orthopedics application.

Due to the good biological and physical properties responses there is interest in intensifying the applications of MTA as a root canal filling material $(11,12)$. However, MTA cement is very well studied relates its biocompatibility properties, few studies were found about the physical properties of the use of MTA as root canal filling material (13). Furthermore, the better understanding of these properties could help to broaden the use of these materials to areas such as restorative dentistry and orthopedics, as it has been suggested $(2,9)$. Thereby, with the possibility of this new application for this material, the aim of this study was to compare two commercial MTA cements regarding their physical properties when used as root canal filling materials.

\section{Methods}

The materials used in this research were Gray MTA ProRoot (Dentsply-Maillefer, Switzerland, batch \# 000721; MTA-P) and MTA Angelus (Angelus, Brazil, batch \# 2773; MTA-A). Both materials were rationed and mixed in accordance with the manufacturer's recommendations and submitted to the tests. The properties evaluated were Compressive Strength, Radiopacity, Solubility, $\mathrm{pH}$ and Setting time. Tests were performed based on ISO 6876-2:2001(14), an update of the ADA/ ANSI 57, that standardizes the procedures to evaluate root canal filling materials. Scanning Electronic Microscopy (SEM) was used to analyze the surface morphology of the cements.

\section{Compressive strength}

Stainless steel segmented cylinder-shape $(12 \mathrm{~mm}$ height $\mathrm{x}$ $6 \mathrm{~mm}$ diameter) was used for to fabricate the specimens. The cements were mixed during 2 min, inserted into the cylinder wells and softly compressed with a glass slab. After $3 \mathrm{~min}$, the set was placed in a cabinet at $37 \pm 2^{\circ} \mathrm{C}$ for $3 \mathrm{~h}$ for setting. Next, the specimens were removed and checked for defects. Six specimens were prepared for each group and stored in distilled water at $37 \pm 2^{\circ} \mathrm{C}$ for $21 \mathrm{~h}$ or 2 weeks. The tests were performed in a universal load machine (Emic DL-500, EMIC, São José dos Pinhais, Brazil) and the maximal load required to fracture the specimen was recorded. This load value was used to calculate the compressive strength with the formula

$$
C S=\frac{4 P}{\pi \cdot D^{2}}
$$

where $P$ is the maximum load and $D$ is the diameter of the specimen.
Radiopacity

Materials were inserted in stainless steel rings $(1.0 \mathrm{~mm}$ height X $10 \mathrm{~mm}$ diameter) sandwiched between two glass slides fixed with c-clamps, and leaved to setting stored in a cabinet at $37 \pm 2{ }^{\circ} \mathrm{C}$ and $95 \%$ relative humidity for 3 hours.

One specimen of each material was evaluated using an occlusal dental film (Kodak Insight, F E Speed, Eastman Kodak Company, Rochester, New York, USA) alongside an aluminum step wedge calibrated from 0.5 up to $9.0 \mathrm{~mm}$ in a dental XRay unit (Gnatus Intra Os 70, P80-002/01, 70 Kvp, $7 \mathrm{~mA}, 120$ VAC 50/60 Hz) The exposure time was 0.20 $\mathrm{s}$ and the distance between the $\mathrm{x}$-ray unit and the film was $30 \mathrm{~cm}$. After processing, radiographic films were digitalized (Genius HR7X Slim 1200 dpi, Taipei, Taiwan) in grayscale, and images analyzed with software Image Toll 3.0 (The University of Texas Health Science Center, San Antonio, Texas, USA).

The amount of white value for each specimen digital image was measured and plotted versus the corresponding density values of the aluminum step wedge. Three specimens for each material were evaluated. A total of three measurements for each specimen were obtained and the average used to compute the data. Value for the radiopacity of each material was expressed in millimeters of aluminum $(\mathrm{mm} \mathrm{Al})$.

\section{Setting time}

Cements were mixed in accordance with the manufacturers' recommendations and inserted in stainless steel rings $(0.5 \mathrm{~mm}$ height $\times 1.0 \mathrm{~mm}$ diameter). After two minutes the mixture was inserted into a cabinet at $35 \pm 2^{\circ} \mathrm{C}$ and $95 \%$ relative humidity. After 30 up to $60 \mathrm{~s}$, two metallic indenters $(190$ and $455 \mathrm{~g}$, with a circular tip of $2 \pm 0.1 \mathrm{~mm}$ ) were alternately positioned on the material surface for $5 \mathrm{~s}$. This procedure was repeated every 5 min until no visible damage on material surface were noticed. Initial setting time was calculated as the period between the mixing begins, and the absence of visible marks caused by the $190 \mathrm{~g}$ indenter. Final setting time was calculated as the period between the mixing begins and the absence of visible damage caused by the $455 \mathrm{~g}$ indenter. For each material, six specimens were evaluated, and the data were reported in minutes.

\section{Solubility}

Specimens used for the solubility test $(2.0 \mathrm{~mm}$ height $\mathrm{x}$ $20 \mathrm{~mm}$ diameter) were fabricated similarly to the radiographic test.

The mass of a glass Petri dish was weighted three times in an analytical scale to the nearest of $0.0001 \mathrm{~g}$ (Bel Ind., Piracicaba, Brazil). Two specimens were positioned in this petri dish, $50 \mathrm{~mL}$ of distilled water was added and the set was stored in a cabinet $\left(37 \pm 1^{\circ} \mathrm{C}\right)$ for $24 \mathrm{~h}$. Afterwards, the specimens were washed with $3 \mathrm{~mL}$ of distilled water, and the petri dish was placed inside a cabinet at $110^{\circ} \mathrm{C}$ (Cabinet SE6, PROLAB, São José dos Pinhais, Brazil) for water evaporation. The Petri dish was stored in desiccators for 
$24 \mathrm{~h}$. Subsequently, new measurement of the Petri dish was performed, and difference between the two measurements was used to express the amount of lost mass. This test was repeated in six different occasions with two new set of specimen in each test.

$\mathrm{pH}$

The $\mathrm{pH}$ was determined using a pHmeter (Q-400A, Quimis, Brazil). The cement was mixed, and one gram was diluted in distilled water until the total mass reached $10 \mathrm{~g}$. The $\mathrm{pH}$ value was measured in three different times: immediately after the dilution, after 1 and $24 \mathrm{~h}$ of dilution. All tests were performed in triplicate.

\section{Scanning Electronic Microscopy}

After manipulation, materials were inserted in stainless steel rings (1.0 $\mathrm{mm}$ height $\mathrm{x} 10 \mathrm{~mm}$ diameter) between two glass slides fixed with c-clamps, and leaved to setting stored in a cabinet at $37 \pm 2{ }^{\circ} \mathrm{C}$ and $95 \%$ relative humidity for 3 hours. Three discs of each material were fixed in metallic stubs with carbon tape (Carbon Tape, 3M, St. Paul, MN, USA), and a layer of $100 \AA$ of gold was deposited over their surface (MED 010, Balzers Union, Balzers, Liechtenstein). The surface morphology was evaluated with a scanning electron microscope (SEM; LEO 435 VP- Carl Zeiss SMT, Oberkochen, Germany) with a $15-\mathrm{kV}$ energy beam. The images were analyzed at $500 \mathrm{X}$ and $1500 \mathrm{X}$ magnification.

\section{Statistical analysis}

Data were analyzed using the statistical software SAS version 9.0; (SAS Institute Inc., Cary, NC). The assumptions of homogeneity of variances and normal distribution of errors were tested for the response variables. Radiopacity, Setting time and Solubility values were assessed using oneway ANOVA, considering the material groups. Compression Strength and $p H$ were analyzed by two-way ANOVA, considering the material groups and period of analyses, followed by the Tukey honestly significant difference (HSD) test. All analyses were performed at $\alpha=0.05$.

\section{Results}

All the physical properties evaluated were in accordance with the ISO 6876-2:2001. The compressive strength, radiopacity and setting time means are presented in Table 1. Regarding compressive strength, both materials showed an increase in their means after water immersion, with MTA-A presenting higher means than MTA-P $(P<0.05)$. Materials showed no significant differences in the radiopacity test $(P<0.05)$. Significant difference were detected $(P<0.0001)$ for setting time means between materials. MTA-P showed the higher means for final setting time.

The means for Solubility and $\mathrm{pH}$ are shown in Table 2. Both materials showed no significant difference $(P>0.05)$ for solubility means. An alkaline $\mathrm{pH}$ for the evaluated materials were detected in the analyses; however no significant differences $(P>0.05)$ were detected between the cements.

Regarding scanning electronic microscopy analysis, the images showed a similar surface morphology to MTA-P and MTA-A (Fig. 1). Due to the water content in the material, a similar pattern of porosity surface was detected in both materials. At higher magnification, a matrix with different granule size was seen. Crystal and amorphous setting pattern also were detected.

Table 1. Comparison of the compressive strength, radiopacity and setting time of the two MTA materials tested as a root canal filling material.

\begin{tabular}{|c|c|c|c|c|c|}
\hline \multirow{2}{*}{ Materials } & \multicolumn{2}{|c|}{ Compressive Strength (KPa) } & \multirow{2}{*}{$\begin{array}{l}\text { Radiopacity } \\
\text { (mm of Al) }\end{array}$} & \multicolumn{2}{|c|}{ Setting Time (min) } \\
\hline & 21 hours & 14 days & & Initial & Final \\
\hline MTA-P & $23.31 \pm 4.32^{\mathrm{a}, \mathrm{A}}$ & $31.36 \pm 16.52^{a, A}$ & $10.7 \pm 0.5^{a}$ & $32.00 \pm 1.26^{a}$ & $179.83 \pm 4.02^{a}$ \\
\hline MTA-A & $37.16 \pm 4.55^{\mathrm{b}, \mathrm{A}}$ & $44.98 \pm 11.28^{\mathrm{b}, \mathrm{A}}$ & $10.8 \pm 0.2^{a}$ & $45.75 \pm 0.50^{b}$ & $144.75 \pm 0.50^{b}$ \\
\hline
\end{tabular}

Different lower case letters show significant differences between materials $(P<0.05)$. Upper case letters show significant differences to periods for compressive strength.

Table 2. Comparison of solubility and $\mathrm{pH}$ of the two MTA materials tested as a root canal filling material.

\begin{tabular}{|c|c|c|c|c|}
\hline \multirow{2}{*}{ Materials } & \multirow{2}{*}{$\begin{array}{c}\text { Solubility } \\
\text { (\% of lost mass) }\end{array}$} & \multicolumn{3}{|c|}{$\mathrm{pH}$} \\
\hline & & Initial & 1 hour & 24 hours \\
\hline MTA-P & $0.09 \pm 0.01^{a}$ & $11.88 \pm 0.03^{a, A}$ & $11.98 \pm 0.02^{a, B}$ & $12.12 \pm 0.08^{a, c}$ \\
\hline MTA-A & $0.12 \pm 0.01^{a}$ & $12.23 \pm 0.01 \mathrm{~b}, \mathrm{~A}$ & $12.34 \pm 0.05^{b, B}$ & $12.22 \pm 0.02^{b, c}$ \\
\hline
\end{tabular}

Different lower case letters show significant differences between materials $(P<0.05)$. Upper case letters

show significant differences in $\mathrm{pH}$ for periods of time. 


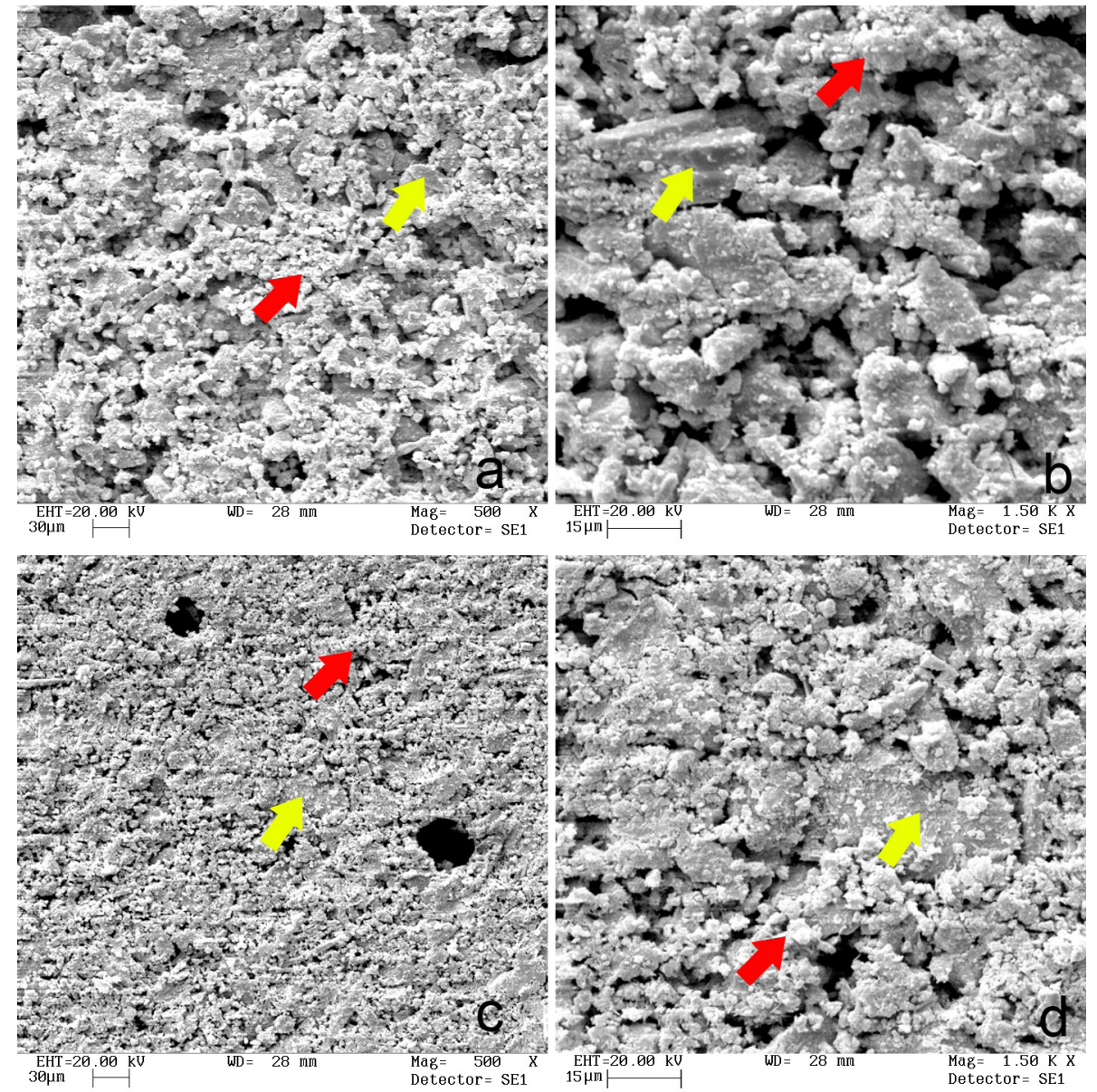

Fig. 1. SEM image of MTA-P $(a, b)$ and MTA-A (c, d) surfaces in $500 \mathrm{X}$ and $1500 \mathrm{X}$ of magnification. High porosity surface can be observed in all materials for both magnifications. Both crystals (yellow arrows) and amorphous (red arrow) phase after setting are present.

\section{Discussion}

The compressive strength is important for dental materials subjected to mechanical loads in service. However, manufacturers and previous studies have indicated MTA cements for clinical applications in areas of indirect load $(2,6,15)$. In the present study, the MTA-A cement exhibited higher compressive strength values than those reported in the literature for MTA cements. The compressive strength of both cements increased after 14 days of water storage as reported previously (2). However, the results of this work showed lower values of compressive strength in the initial and final time measures. The variability in the means of compressive strength can be explained by the different period of water storage ( 3 and 28 days) used instead of the period of time suggested by ISO 6876:2001 (21 hours and 14 days).

The radiopacity of dental materials have been measured in equivalent millimeters of aluminum ( $\mathrm{mm} \mathrm{Al})$. According to Tagger and Katz (16), due to the proliferation of rootend filling materials with a broad range of radiopacity, an international standard stipulating the required minimal radiopacity is needed urgently. The ISO 6876-2:2001 (14) recommends opacity values higher than $3 \mathrm{~mm} \mathrm{Al}$ for dental root sealing materials. The radiopacity of root-end filling materials have been shown to range from 1.75 up to $>10 \mathrm{~mm}$ $\mathrm{Al}$, with the lower range claimed to be insufficient for routine clinical detection (16). The radiopacity of the commercials MTA is mainly attributed to the presence of radiopacifiers (e.g., bismuth oxide) in its composition (17-19).

In this study, all materials exhibited values of setting time within the limits of ISO 6876-2(14). Moreover, MTA cements exhibited values similar to those reported in literature $(13,20)$. The long setting time exhibited for both MTA cements may be insufficient to prevent the displacement of the material in their multiple clinical applications, which is an advantage. The ISO 6876-2:2001 (14) recommends solubility values not higher than $3 \%$ for dental root sealing materials, and the absence of surface degradation under visual inspection. In this study, both materials exhibited solubility values within this limit as reported previously $(13,21,22)$. In another study, the MTA cement did not show any solubility (20), which can be explained by differences in methodology.

The present study detected slightly higher values of $\mathrm{pH}$ for MTA-A than MTA-P, which was reported before by Duarte et al. (23). Moreover, the MTA-P material exhibited the lowest $\mathrm{pH}$. Other studies have found lower $\mathrm{pH}$ values of MTA cements $(21,22,24)$. The alkaline nature of mineral trioxide aggregate is justified by the presence of calcium oxide in the composition, which reacts with water and 
dissociates releasing hydroxyl and calcium ions. The main sources of hydroxyl ions comprise the $\mathrm{O}^{-2}$ ions from the silicate tetrahedral links and the dissolution of $\mathrm{CaO}$, while the secondary sources comprise the sodium and potassium alkalis present at low concentrations (18). Future studies should elucidate the biological effects of different $\mathrm{pH}$ values on the surrounding tissues.

The overall $\mathrm{pH}$ of the materials was initially lower compared with the period of 1 hour. This might be related to the initial high contents of hydroxyls formed. In contrast, after $24 \mathrm{~h}$ of water immersion, the overall $\mathrm{pH}$ of the materials was lower compared to the initial values. The neutralization of the calcium hydroxide by its reaction with carbon dioxide from the surrounding water or atmospheric air might explain this finding.

The surface characteristics of mineral trioxide materials such as its porosity and its particle size or granulation are directly related with the spread and adhesion in the initial phase of cellular function (9), and also are of great importance for the mechanical characteristics (25). The material showed a highly porous matrix, similarly to the findings of previous studies (25). This porosity and the aspect of the matrix can explain the good response in biological aspects of the MTA. As described previously $(17,20)$, MTA exhibits both crystalline and amorphous phases after setting (Fig. 1). This is in accordance with the SEM analyses of the evaluated materials.

\section{Conclusions}

Both materials showed similar results for the evaluated properties and are in accordance with the ISO 6876-2: 2001, allowing them for use as a root canal filling material. However, biological tests and clinical trials are still necessary to evaluate these materials for a broad clinical use.

\section{References}

1. Lee SJ, Monsef M, Torabinejad M. Sealing ability of a mineral trioxide aggregate for repair of lateral root perforations. J Endod 1993; 19:541-4

2. Abdullah D, Ford TR, Papaioannou S, Nicholson J, McDonald F. An evaluation of accelerated Portland cement as a restorative material. Biomaterials 2002;23:4001-10.

3. Accorinte Mde L, Holland R, Reis A, Bortoluzzi MC, Murata SS Dezan $E$, Jr. et al. Evaluation of mineral trioxide aggregate and calcium hydroxide cement as pulp-capping agents in human teeth. J Endod 2008;34:1-6.

4. Bortoluzzi EA, Broon NJ, Bramante CM, Consolaro A, Garcia RB, de Moraes IG et al. Mineral Trioxide Aggregate with or without Calcium Chloride in Pulpotomy. J Endod 2008;34:172-5.

5. Brun DF, Brun DF, Kopper PMP, Grecca FS. Apical internal inflammatory root resorption and open apex treated with MTA: a case report. Rev Odonto Ciênc. 2010;25:213-5.

6. Ford TR, Torabinejad M, McKendry DJ, Hong CU, Kariyawasam SP. Use of mineral trioxide aggregate for repair of furcal perforations. Oral Surg Oral Med Oral Pathol Oral Radiol Endod 1995;79:756-63.

7. Holland R, de Souza V, Nery MJ, Faraco Junior IM, Bernabe PF, Otoboni Filho JA et al. Reaction of rat connective tissue to implanted dentin tube filled with mineral trioxide aggregate, Portland cement or calcium hydroxide. Braz Dent J 2001;12:3-8.

8. Koh ET, Torabinejad M, Pitt Ford TR, Brady K, McDonald F. Mineral trioxide aggregate stimulates a biological response in human osteoblasts. J Biomed Mater Res 1997;37:432-9.

9. Al-Rabeah E, Perinpanayagam H, MacFarland D. Human alveolar bone cells interact with ProRoot and tooth-colored MTA. J Endod 2006;32:872-5

10. do Nascimento C, Issa JP, lyomasa MM, Regalo SC, Siessere S, Pitol $\mathrm{DL}$ et al. Bone repair using mineral trioxide aggregate combined to a material carrier, associated or not with calcium hydroxide in bone defects. Micron 2007;39:868-74.

11. Holland R, de Souza V, Nery MJ, Otoboni Filho JA, Bernabe PF, Dezan Junior E. Reaction of dogs' teeth to root canal filling with mineral trioxide aggregate or a glass ionomer sealer. J Endod 1999:25:728-30.

12. Maroto M, Barberia E, Planells P, Vera V. Treatment of a non-vital immature incisor with mineral trioxide aggregate (MTA). Dent Traumatol 2003;19:165-9.
13. Islam I, Chng HK, Yap AU. Comparison of the physical and mechanical properties of MTA and portland cement. J Endod 2006:32:193-7.

14. International Organization for Standardization. International Standard ISO 6876:2001: Dental Root Canal Sealing Materials. Geneva: International Organization for Standardization; 2001.

15. Torabinejad $M$, Chivian N. Clinical applications of mineral trioxide aggregate. J Endod 1999;25:197-205.

16. Tagger M, Katz A. A standard for radiopacity of root-end (retrograde) filling materials is urgently needed. Int Endod J 2004;37: 260-4.

17. Asgary S, Parirokh M, Eghbal MJ, Brink F. Chemical differences between white and gray mineral trioxide aggregate. J Endod 2005;31:101-3

18. Estrela C, Bammann LL, Estrela CR, Silva RS, Pecora JD. Antimicrobial and chemical study of MTA, Portland cement, calcium hydroxide paste, Sealapex and Dycal. Braz Dent J 2000;1 1:3-9.

19. Leites AC, Figueiredo JAPd, Demarco FF, Basso AP, Piva E. Radiopacity of the modified Portland cement in comparison with MTA. Rev Odonto Ciênc 2008;23:145-9.

20. Torabinejad M, Hong CU, McDonald F, Pitt Ford TR. Physical and chemical properties of a new root-end filling material. J Endod $1995 ; 21: 349-53$

21. Fridland $M$, Rosado R. Mineral trioxide aggregate (MTA) solubility and porosity with different water-to-powder ratios. J Endod 2003;29:814-7.

22. Fridland M, Rosado R. MTA solubility: a long term study. J Endod 2005;31:376-9

23. Duarte MA, Demarchi AC, Yamashita JC, Kuga MC, Fraga Sde C. $\mathrm{pH}$ and calcium ion release of 2 root-end filling materials. Oral Surg Oral Med Oral Pathol Oral Radiol Endod 2003;95: 345-7.

24. Bortoluzzi EA, Broon NJ, Hungaro Duarte MA, Demarchi AC, Bramante CM. The use of a setting accelerator and its effect on $\mathrm{pH}$ and calcium ion release of mineral trioxide aggregate and white Portland cement. J Endod 2006;32:1194-7.

25. Dammaschke T, Gerth HU, Zuchner H, Schafer E. Chemical and physical surface and bulk material characterization of white ProRoot MTA and two Portland cements. Dent Mater 2005;21: 731-8. 